\title{
Gender Differentials in Education
}

\author{
K. Khasimpeera, M. Sugunatha Reddy
}

\begin{abstract}
The authors talk about a portion of the social factors and practices that confine ladies' entrance to training. The apparent requirement for offering training to females would be distinctive for various gatherings and with certain gatherings they may be no felt want for educating women. A few humans may additionally need to teach their daughters and they have become able to earning an income. For others, training can be greater a standing considered necessary most effective know how and belief to get right of entry to education and the high-quality of training additionally be made.

Keyword: training, Education, women,
\end{abstract}

\section{INTRODUCTION}

The education expense in the nation is fifty two.21 Per cent. In any case, male proficiency costs are significantly superior to those of the females. Sixty-4 in step with penny of the men is proficient while least complex 39.Three predictable with penny of the young ladies is educated. In spite of the fact that those figures were improving over the in quite a while, in all the states male proficiency cites are superior to anything young lady education expenses. Indeed, even in states like Kerala in which the greater part are educated 93.62 of the men are proficient while in assessment just 86.14 of the young ladies are educated. In states like Rajasthan this differentiation is a horrendous part more extensive, best 20 as indicated by penny of the ladies are proficient while 55 in accordance with penny of the guys are taught.

\section{METHODOLOGY}

It is a process of surveying women candidates in different states of India. From different women candidates of different states in India receive different views in the manner of oral discussion. Stratified random sampling used in this survey and extract male female literacy rate and education status of girls in between age group of 6-14.

\section{RESULT ANALYSIS}

The following Tables 01 and 02 provides the educational status of selected states in India and with charts

Table 01: Male - Female literacy rates in selected states of India

\begin{tabular}{|l|c|c|c|}
\hline \multicolumn{4}{|c|}{ Male - Female literacy rates in selected states of India } \\
\hline \multicolumn{3}{|c|}{ STATES } & \multicolumn{3}{c|}{ TOTAL POPULATION } \\
\hline & Persons & Males & Females \\
\hline BIHAR & 38.48 & 52.49 & 22.89 \\
\hline CHANDIGARH (U.T) & 52.21 & 64.13 & 39.29 \\
\hline GUJARAT & 61.29 & 73.13 & 48.64 \\
\hline
\end{tabular}

Revised Manuscript Received on February 05, 2020.

* Correspondence Author

K. Khasimpeera*, Assistant Professor, Dept. of Humanities \& Sciences, K.S.R.M.College of Engineering (Autonomous), Kadapa, Andhra Pradesh -516003, India. Mail Id: khasim.mba@gmail.com

Dr. M. Sugunatha Reddy, Assistant Professor, Dept. of Humanities \& Sciences, K.S.R.M.College of Engineering (Autonomous), Kadapa, Andhra Pradesh -516003, India.

(c) The Authors. Published by Blue Eyes Intelligence Engineering and Sciences Publication (BEIESP). This is an open access article under the CC BY-NC-ND license (http://creativecommons.org/licenses/by-nc-nd/4.0/)

\begin{tabular}{|l|l|l|l|}
\hline HARYANA & 55.85 & 69.10 & 40.47 \\
\hline KERALA & 89.81 & 93.62 & 86.17 \\
\hline MIZORAM & 82.27 & 85.61 & 78.60 \\
\hline PUNJAB & 58.51 & 65.66 & 50.41 \\
\hline RAJASTHAN & 38.55 & 54.99 & 20.44 \\
\hline TAMIL NADU & 62.66 & 73.75 & 51.33 \\
\hline UTTAR PRADESH & 41.60 & 55.73 & 25.31 \\
\hline
\end{tabular}

Source: Census of India, 2001

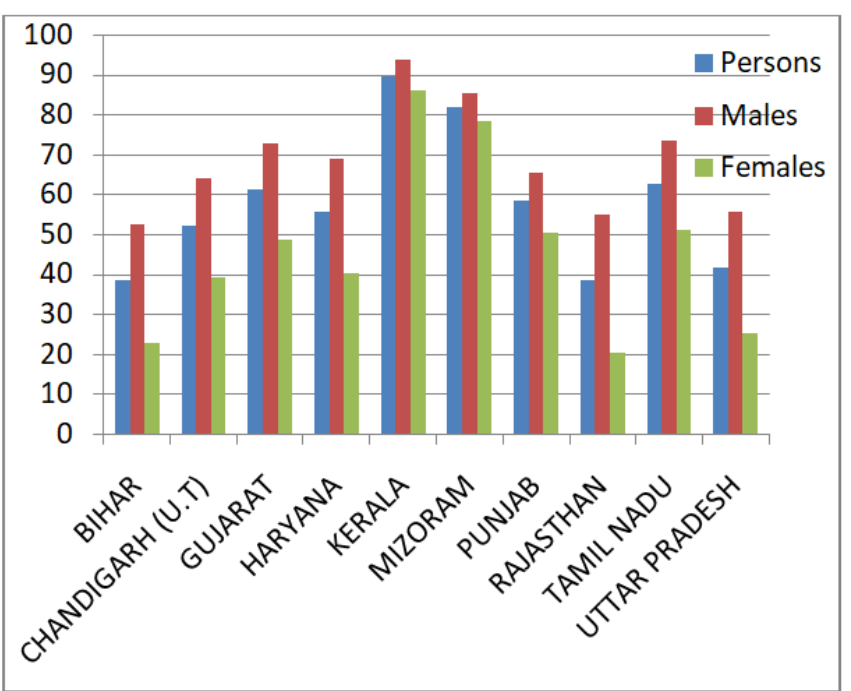

The following table provides the educational status of the girls aged of the girls 6-14 years child in some states of India.

Table 02: Educational status of the girls aged 6-14 years

\begin{tabular}{|c|c|}
\hline \multicolumn{2}{|c|}{$\begin{array}{c}\text { EDUCATIONAL STATUS OF THE GIRLS } \\
\text { AGED 6-14 YEARS }\end{array}$} \\
\hline STATES & $2002-2003(\%)$ \\
\hline ANDHRA PRADESH & 45 \\
\hline ASSAM & 34 \\
\hline BIHAR & 62 \\
\hline GUJARAT & 32 \\
\hline HARYANA & 25 \\
\hline HIMACHAL PRADESH & 12 \\
\hline KARANATAKA & 36 \\
\hline KERALA & 5 \\
\hline MADHYAPRADESH & 45 \\
\hline MAHARASHTRA & 23 \\
\hline ORISSA & 38 \\
\hline PANJAB & 22 \\
\hline RAJASTHAN & 59 \\
\hline TAMIL NADU & 22 \\
\hline UTTAR PRADESH & 52 \\
\hline WEST BENGAL & 37 \\
\hline INDIA & 41 \\
\hline
\end{tabular}

Source: National Family Health Survey, 2002-03.

Published By:

Blue Eyes Intelligence Engineering

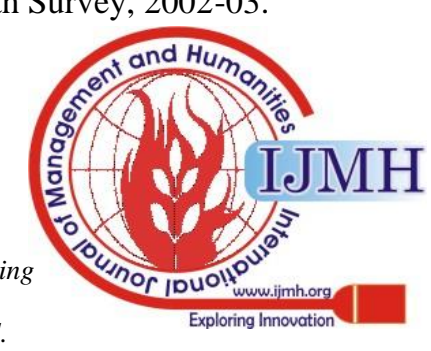




\section{Gender Differentials in Education}

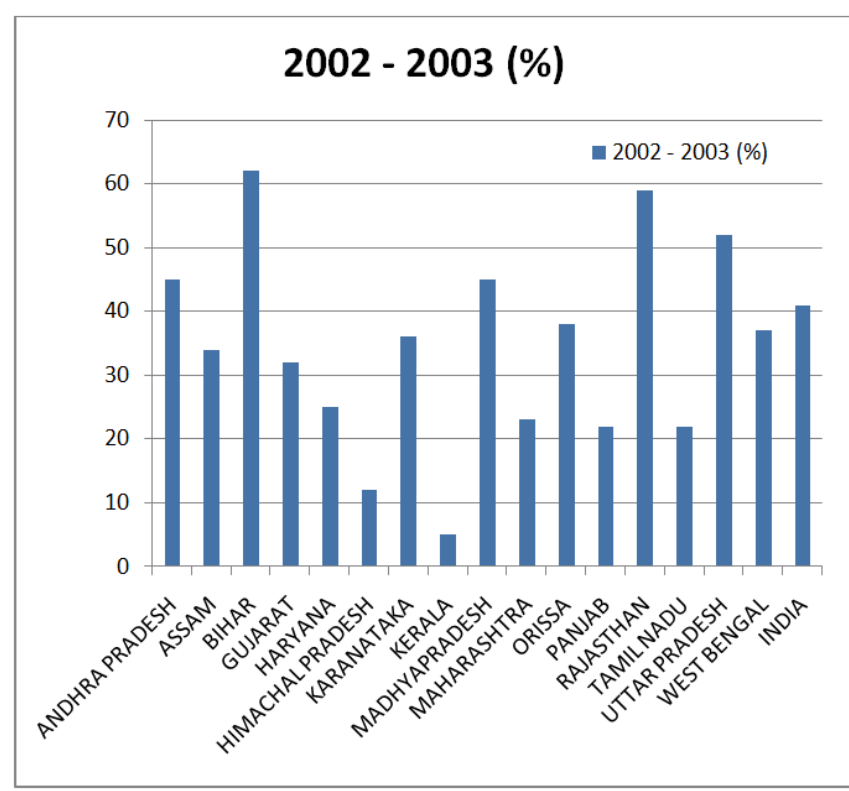

Other than the varieties inside the preparation charges among women and men, there are a couple of different dissimilarities, In the urban locales the education cites are bounty better and 64.05 predictable with penny of the women inside the city districts are proficient in examination 30.Sixteen with regards to penny in the rustic areas. Differences additionally exist from nation to state.

The nation of Kerala has the most elevated proficiency rate for women wherein eighty three.9 percent of them are instructed. On the elective hand, states like Rajasthan and Bihar have awful female education paces of 20.Eight percent separately.

\section{Differential Education:-}

Guys and Females are outfitted access to remarkable styles of tutoring. As per the male situation of workers, they're given instruction and capacities that have gainful worth. Females, on the other hand, gain preparing and abilities identifying with infant care and home assignments. For instance, additional young men are a piece of productions alongside exchange and mechanical skill while women are major in expressions, sociology and home science. For instance, the to be had insights for 2005 for the province of Punjab shows that 99.7 in accordance with penny of the researchers in agribusiness related abilities, 67 in step with penny in assembling, 75 as indicated by penny in designing and structure had been male understudies. In correlation, in nourishment related circles (which incorporates cooking and providing food) a hundred percent understudies were ladies.

Table 03: Rural literacy rates for males and females in selected states of India

\begin{tabular}{|l|c|c|c|}
\hline \multicolumn{4}{|c|}{$\begin{array}{c}\text { RURAL LITERACY RATES FOR MALES AND } \\
\text { FEMALES IN SELECTED STATES OF INDIA }\end{array}$} \\
\hline \multicolumn{2}{|c|}{ STATES } & \multicolumn{3}{c|}{ RURAL POPULATION } \\
\hline & Persons & Males & Females \\
\hline ANDHRA PRADESH & 35.74 & 47.28 & 23.92 \\
\hline $\begin{array}{l}\text { ARUNACHAL } \\
\text { PRADESH }\end{array}$ & 37.02 & 47.00 & 25.31 \\
\hline BIHAR & 33.83 & 48.31 & 17.95 \\
\hline KERALA & 88.92 & 92.91 & 85.12 \\
\hline
\end{tabular}

\begin{tabular}{|l|l|l|l|}
\hline MADHYA PRADESH & 35.87 & 51.04 & 19.73 \\
\hline PUNJAB & 52.77 & 60.71 & 43.85 \\
\hline RAJASTHAN & 30.37 & 47.64 & 11.59 \\
\hline UTTAR PRADESH & 36.66 & 52.05 & 19.02 \\
\hline WEST BENGAL & 50.50 & 62.05 & 38.12 \\
\hline INDIA & $\mathbf{4 4 . 6 9}$ & $\mathbf{5 7 . 8 7}$ & $\mathbf{3 0 . 6 2}$ \\
\hline
\end{tabular}

Source: Census of India, 2001

Table 04: Urban literacy rates for males and females in selected states of India

\begin{tabular}{|c|c|c|c|}
\hline \multicolumn{4}{|c|}{$\begin{array}{l}\text { RURAL LITERACY RATES FOR MALES AND } \\
\text { FEMALES IN SELECTED STATES OF INDIA }\end{array}$} \\
\hline \multirow[t]{2}{*}{ STATES } & \multicolumn{3}{|c|}{ URBAN POPULATION } \\
\hline & Persons & Males & Females \\
\hline ANDHRA PRADESH & 66.36 & 75.87 & 56.41 \\
\hline $\begin{array}{l}\text { ARUNACHAL } \\
\text { PRADESH }\end{array}$ & 71.59 & 77.99 & 62.23 \\
\hline BIHAR & 67.89 & 77.72 & 55.94 \\
\hline KERALA & 92.25 & 95.58 & 89.06 \\
\hline MADHYA PRADESH & 70.81 & 81.32 & 58.92 \\
\hline PUNJAB & 72.08 & 77.26 & 66.12 \\
\hline RAJASTHAN & 65.33 & 78.50 & 50.24 \\
\hline UTTAR PRADESH & 61.00 & 69.98 & 50.38 \\
\hline WEST BENGAL & 75.27 & 81.19 & 68.25 \\
\hline INDIA & 73.08 & 81.09 & 64.05 \\
\hline
\end{tabular}

Source: Census of India, 2001

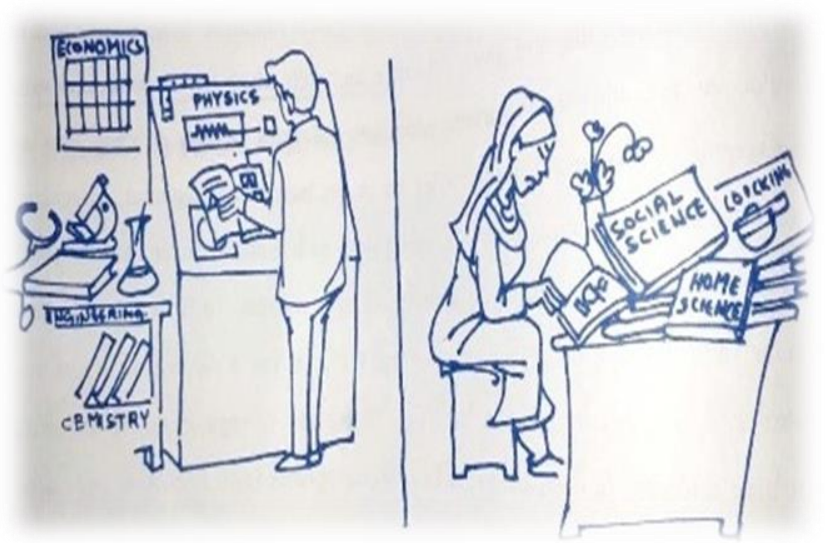

\section{Socio-Cultural Milieu:-}

Social outlooks, feelings and norms think about women's poor access to guidance. Differences in male-female capability levels, differentiates in urban and nation female training levels and fluctuating instruction levels in different state do point out that inside the available enlightening system females face social partition - both in access to preparing and in the idea of guidance open to them. Social benchmarks turn around a woman's activity as the nurturer of the family. Along these lines, constrained access to female preparing is progressed not simply by the family (a youngster is a "paraya dhan", teaching her is an abuse of money). Thusly if introduction through guidance can annihilate a youngster's character, by then preparing must be avoided. A mix of these parts chooses the socio-social atmosphere that limits female access to preparing.

Published By:

Blue Eyes Intelligence Engineering

\& Sciences Publication

(C) Copyright: All rights reserved.

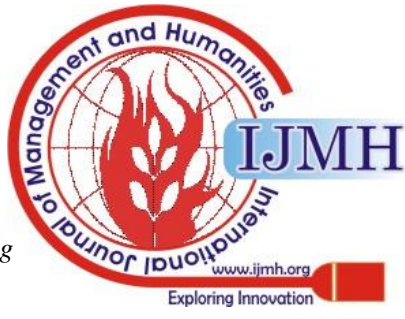




\section{Utilization of Education for Females:-}

The prerequisite for guidance for folks and females is seen with respect to the occupations they are depended upon to play. For women these employments turn around the home and child care. For folks, the supplier is the model. Socialization procedure and looking at practices, demeanors and direct reinforce these limits.

\section{1) Requirement for Educating Females :}

In various zones of society, training youngsters isn't viewed as a social family and financial need. Since a female's activity is viewed as being kept to nuclear family activity, preparing in itself may not be regarded. Subsequently, a youngster not given preparing. Or maybe, she may deal with her kinfolk and nuclear family errands.

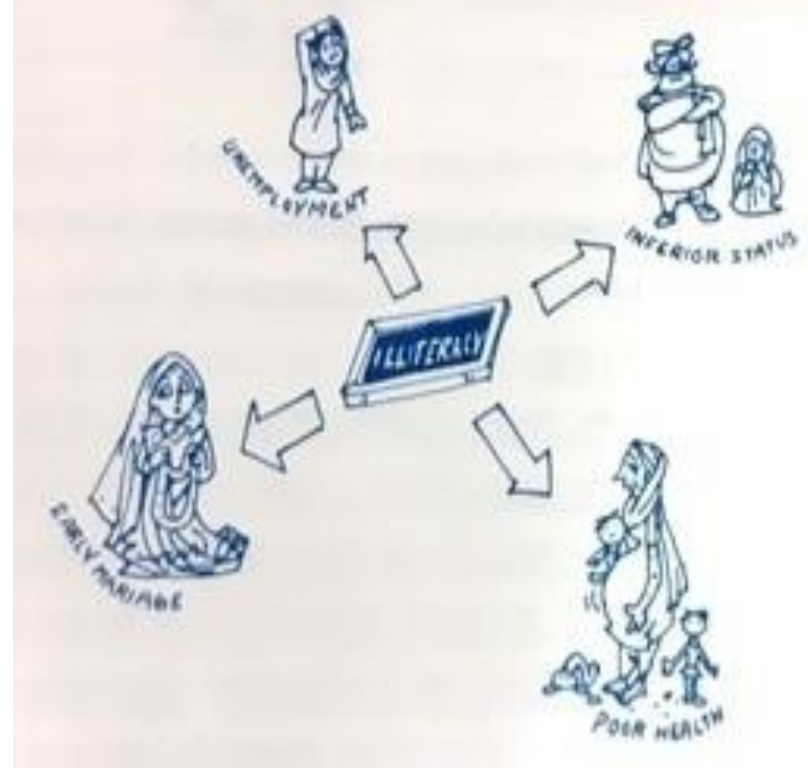

1)Status:-

a) Training drop outs of family status

b) An essential to marriage

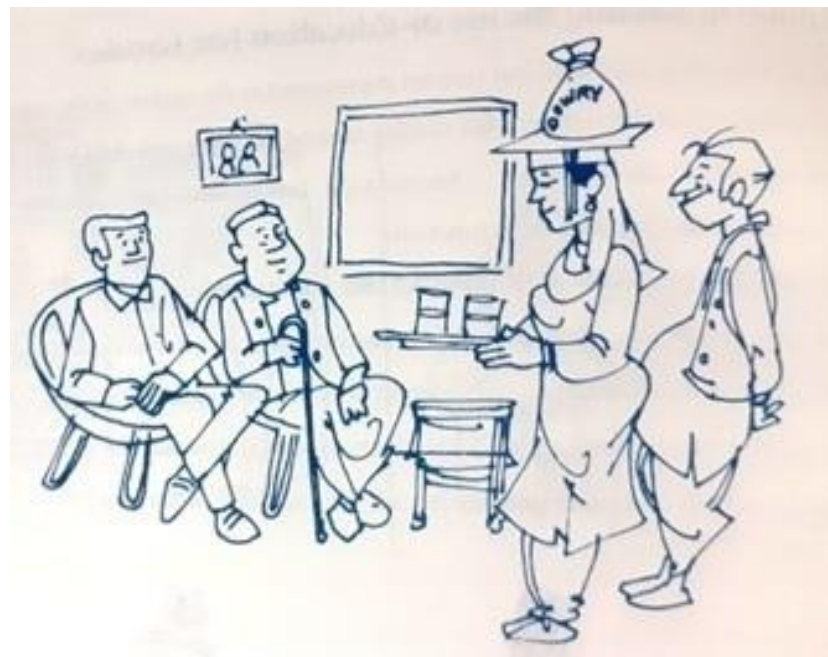

Preparing, rather the "perfect level" of guidance for youngsters is imagined concerning the status of the family and as a capability factor with respect to marriage. A gathering of status offers guidance to its youngster youths. In such a setting preparing itself is seen as a value. Also, an educated youngster has a status, the enthusiasm for which contrasts from zone to zone, according to the stratum, position, religion and other social parts. In like way, in the nation place/upper strata, youngsters may require a statement of eighth pass. In the urban domains youngsters may be told up to the graduated class level or as required by qualified marriage assistants. In various settings, preparing may give a budgetary status despite the monetary prosperity for improving capability for marriage. Right now women may be instructed up to enlistment or put in IT Is with the objective that they could take up occupations if so needed by their folks in law. For instance, if a youngster has passed the tenth class, she can learn type-creating or be equipped for a Gram Sevika's post. Right now youngster can get a compensation, if her family condition so demands, yet it remains discretionary to her activity as a family nurturer.

\section{2) Education compared to Literacy and Employment :}

Guidance compared with capability and work and correspondingly, the criticalness given to training her relates to the essentials of her matrimonial home. The notable idea is that preparation gives capability and is a pre-basic for business. Impression of preparing as a vehicle of care, information or presentation stays ruined. Preparing isn't imagined as an approach to accomplishing a powerful character, and making an equipped and certain person. Given such obstructions with which the necessity for guidance is appreciated, its utility for youngsters as far as anyone knows is inconsequential. In all honesty, neighborhood sayings, for instance, "Ladki kya padkar patwari/munim banegi?" highlight the activity ascribed to guidance, where the activity of a specialist isn't simply denied to women anyway as moreover disparaged. Youngsters are on a very basic level educated to achieve capability. At the point when that is cultivated, no further need is imagined since youngsters are not expected to endeavor the activity of laborers.

\section{Restricting to Female Education:-}

\section{Stereo types in Education:-}

Supporting the rationale of man centric society that young ladies have distinctive social jobs, their direct and values are administered by standards, for example, celibacy, womanliness and purda, which limit ladies' entrance to training. A portion of these generalization convictions and practices are :

\section{a) Education gives presentation to young ladies which "ruins" them:}

Young ladies, after pubescence which implies on arriving at the center school level, are limited to the bounds of the home. It is ordinarily accepted that young ladies, if not held under steady supervision and check, and permitted to blend uninhibitedly with young men, may even abscond or lose their virtue. The estimation of modesty which confines portability has power over instruction for example containing ladies inside the man centric standards is seen to be a higher priority than making them confident.

Published By:

Blue Eyes Intelligence Engineering 


\section{Gender Differentials in Education}

Introduction and association with the outside world may even bring about releasing of control of the guardians. It can brings about the young lady's scrutinizing the guardians' activities or needing to have a more noteworthy state in issues concerning their lives. For example, the sort of kid she needs to wed or where she needs to examine. It might even be the sort of dress the young lady needs to wear. All these generalization rehearses relate all the more explicitly to young ladies who have achieved pubescence. Again such practices reduce the ladies' opportunity exposing them to the control of oppressing standards and estimations of man centric society.

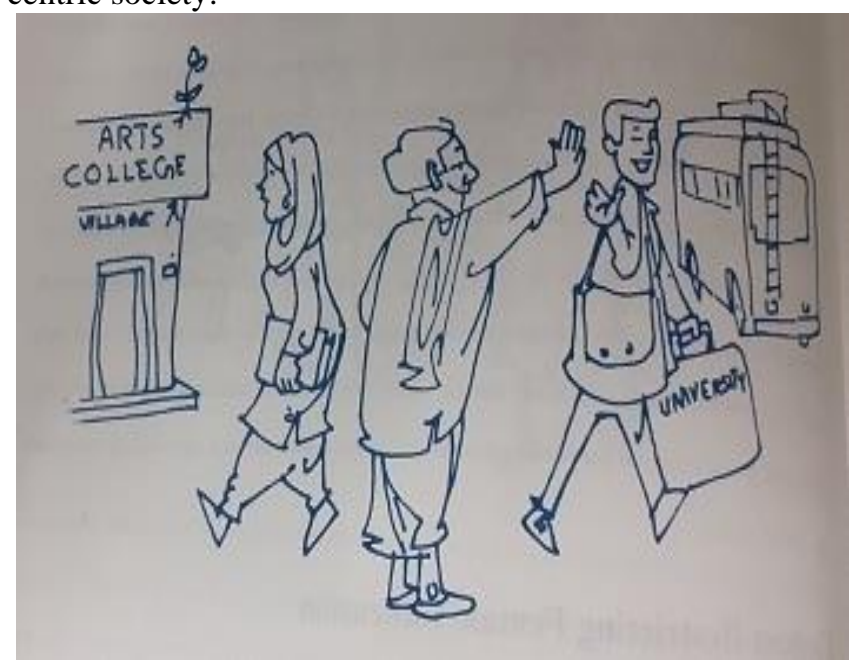

\section{Girls are dim witted:-}

One of the notable musings which is used to explain class at all is that youngsters are normally and mentally inferior and unequipped for being told. Such feelings are useful to restrict the youngsters to the limits of the house and all the while start them to running a nuclear family.

\section{Girls have no enthusiasm for examines:-}

Guardians may state that they need to instruct the young lady further however the young lady herself isn't keen on contemplates since she continues flopping in her assessments. The purposes behind her disappointment or the purported senility might be that she is continually involved in family unit errands or is herself the casualty of the belief system that the family is her space and she isn't relied upon to gain a salary in this way there is no requirement for study. Education young ladies is an exercise in futility and cash:-

Since youngsters are not expected to grasp occupations, training them is accepted to be a pointless activity and effort. Or maybe, they are encouraged to be proficient in home life, have some ability in running the family. Such feelings are direct related to the stereotyped activity of female nurturers and watchmen.

\section{1) Practices :-}

Supporting the speculations and contemplations on young woman kid guidance there are certain practices which either deter the preparation of the youngster youth or further the uneven idea of guidance open to her.

\section{Codes of lead:-}

Children are related into good lead where airs and direct are over man driven benchmarks. For instance, youngsters youngster's dropping out of school or not sending them to

are depended upon to go to class and get back home authentically.

Buying things from dealers, staying back for games or extracurricular activities, etc., isn't a sufficient direct. Preparing doesn't transform into a way of life and remains only a requirement for getting instructed.

\section{Dress codes:-}

Dress is savvy of the preservationist and right lead identifying with male driven benchmarks. In reality, even in schools, regulated appearance is maintained for fear that youngsters don't get singled out for thought. Equivalent rules might not have any noteworthy bearing to youngsters who have progressively unmistakable chance and choice even in their outward appearance. Such lead subintentionally advocates the particular socialization instances of folks and females. It limits female choices even on such typical issues as appearance, where even guidance reunderlines the guidelines of purda, unobtrusiveness and alluring character of women.

\section{Social boundaries:-}

Other than the way of thinking and the relating feelings and practices that are overwhelming, there are a couple of hindrances to woman being educated. A part of these are :

\section{Creating a lopsidedness in the male-female hierarchy:-}

Given the present sex structure, male assistants are depended upon to have higher aptitudes and ideal preparing abilities over their mates. If the female is logically revealed or instructed, by then she may examine her life partner or turn into a prevalent pioneer. The fear of an over-educated youngster not finding a life partner limits the preparation open to women, emphasizing their subordinate position.

\section{Avenue for eve-pushing and assault:-}

The man centric condition encourages provocation of young ladies. Binding and limiting them to the home stays away from such inconveniences as it were. On the off chance that a young lady needs to go to school routinely or even get down to business, at that point, to that degree, she is presented to male development.

\section{Sibling guardian and family errands entertainer:-}

Inside the home, the young lady kid is required to perform different family errands and furthermore to care for the kids. Since paid assistance may not be accessible or attractive, and help from male individuals isn't anticipated, ladies perforce need to depend on little youngsters for help. In addition, since the young ladies are relied upon to play out these capacities all through their lives, they are ingrained to these jobs. In this manner training may turn into a weight to the youthful female.

\section{Effect of differential instruction young ladies:-}

$>$ Girls might be denied instruction

$>$ They might be furnished with some instruction (till the eighth or registration standard)

$>$ The nature of instruction gave might be poor (young ladies concentrating in local schools or furnished with low quality training)

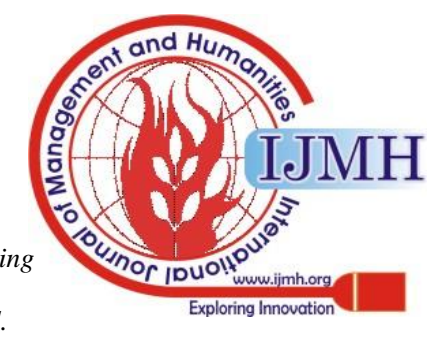


The nature of instruction given to them identifies with their residential capacities, for example, home science, youngster care, sustenance and so on.

Even in the circle of instruction, young ladies are limited to bring down market esteem alternatives, for example, sociologies. There are less young ladies in business or science.

\section{CONCLUSION}

Recollecting that any productive intercession needs a correct view of the issue can be overseen feasibly, it must bolstered on field level issues, stereotyped practices that hamper women's passage to and value in guidance. It is such inclination that must be steered to fight restrictions on women and the inferior position consented to them.

\section{REFERENCES}

1. Hand book, S.V.University, Tirupati, S.V.U Publication, 2001.

2. Hand book of women survey 2001.

3. National sample survey 2002.

4. Directorate of Medical and health Department, Delhi, 2002.

\section{AUTHOR PROFILE}

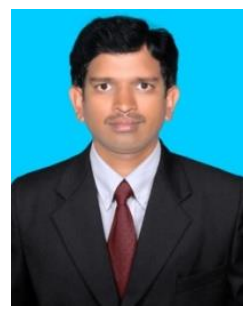

Khasimpeera. K

C/o. Rajamma

D.NO.- 3/2020

Raja Reddy Street, Sionpuram, Kadapa - 516001

Mob: +919966367517

Email: khasim.mba2011@gmail.com

\begin{tabular}{|c|c|c|}
\hline COURSE & INSTITUTION & $\begin{array}{c}\text { YEAR } \\
\text { OF } \\
\text { PASSED }\end{array}$ \\
\hline M.B.A & s.v.university & 2013 \\
\hline M.COM & $\begin{array}{c}\text { Yogi vemana University college, } \\
\text { vemanapuram }\end{array}$ & 2011 \\
\hline PGDCA & $\begin{array}{c}\text { J.R.Educational Trust } \\
\text { Computer Education and Training. }\end{array}$ & 2008 \\
\hline B.COM & $\begin{array}{c}\text { Gov't degree college for men, } \\
\text { kadapa }\end{array}$ & 2007 \\
\hline $\begin{array}{c}\text { INTERMEDIATE } \\
\text { (CEC) }\end{array}$ & R.E.S.S.V. Jr college, khajipet. & 2002 \\
\hline SSC & Z.P. Boy's High School, khajipet. & 2000 \\
\hline
\end{tabular}

Professional Career Summary:

- Worked as Assistant Professor in Balaji institute of I.T \& Management, Kadapa.(01/09/2011 TO 11/12/2012)

- Working as Assistant Professor in K.S.R.M. Engineering college (AUTONOMOUS), Kadapa.(12/12/2012 TO Till Date )

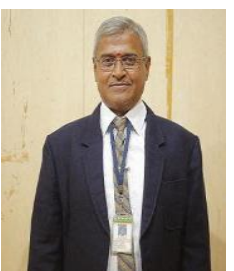

Dr. Sugunatha Reddy, M.

Professor in Humanities and Sciences,

KSRM College of Engineering, Kadapa - 516003.

(A.P.)

E-mail: msnreddy1457@gmail.com

Contact No: 9966296511

\begin{tabular}{|c|c|c|}
\hline QUALIFICATION & UNIVERSITY & PERCENTAGE \\
\hline Ph.D & S.K. University & --- \\
\hline M. Phil & S.K. University & 65 \\
\hline M.A. & S.V. University & 62.5 \\
\hline PGDPM & ACG, New Delhi & 62 \\
\hline
\end{tabular}

Professional Career Summary:

12-08-1999 to 31-03-2017, as a Associate Professor \& HOD,

Humanities

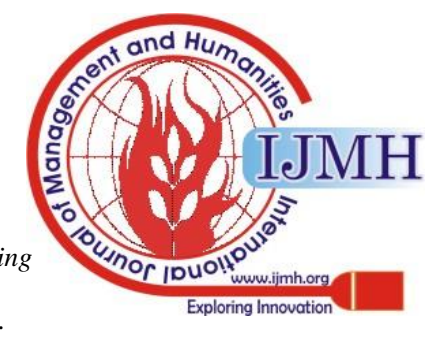

